\title{
PELUANG INDUSTRI DAN PERDAGANGAN INDONESIA DALAM PELAKSANAAN MASYARAKAT EKONOMI ASEAN
}

(Industry and Trade Opportunity of Indonesia on Asean Economic Community)

\author{
Syprianus Aristeus \\ Pusat Penelitian dan Pengembangan Sistem Hukum Nasional \\ Badan Pembinaan Hukum Nasional \\ Email: siprianus@bphn.go.id
}

Naskah diterima: 21 Mei 2014; revisi: 25 Agustus 2014; disetujui: 27 Agustus 2014

\begin{abstract}
Abstrak
Kebijakan perdagangan bebas, dan pasar tunggal ASEAN pada tahun 2015 harus dapat dilaksanakan sesuai dengan kesepakatan yang telah dibuat. Sebagai pasar tunggal baik di perdagangan bebas maupun ASEAN semua hambatan perdagangan khususnya seperti tarif akan dihapuskan, antisipasi terutama harus kita lakukan adalah terkait dengan liberalisasi sektor jasa sebagai sektor sensitif, adapun lima sektor tersebut adalah jasa kesehatan, pariwisata, e-commerce, transportasi udara dan logistik. Kelimanya akan efektif pada tahun 2015 mendatang. Untuk itu akan dibahas bagaimana pelaksanaan pasar bebas MEA di Indonesia dan bagaimana antisipasi pemerintah Indonesia dengan diberlakukan WTO serta Kehadiran Undang-undang Perindustrian dan Perdagangan. Dengan menggunakan metode penelitian hukum normatif, hasil penelitian menunjukkan bahwa negara-negara di dunia yang terlibat langsung dalam perdagangan bebas mempunyai hak untuk menjual produk baik barang ataupun jasa terhadap negara lain tanpa harus dibebani oleh batasanbatasan pajak atau bea masuk, serta peraturan yang membelenggu. Untuk itu harus segera dijalankan sebuah transformasi industrialisasi berdasarkan sebuah kebijakan industrial yang selektif. Hal ini perlu dilakukan salah satunya dengan cara penguatan peran Kementerian Perindustrian dan Perdagangan menjadi satu kementerian-agar ada satu kebijakan industri yang kuat dan bahwa kebijakan perdagangan dan investasi harus menginduk kepada kebijakan industri.
\end{abstract}

Kata Kunci: globalisasi, industri, investasi

\section{Abstract}

Free trade policy-and the ASEAN single market in 2015 must be implemented in accordance with the agreements that have been made. Either as a single market in free trade and ASEAN all trade barriers such as tariffs will be abolished in particular, the main anticipation to do is related to the liberalization of the service sectors as a sensitive sectors, thre are five service sectors such as health services, tourism, e-commerce, air transportation and logistics. Those sectors will be effective soon in 2015. In accordance to discuss how the implementation of ASEAN Economic Community free trade in Indonesia; and how Indonesian government anticipate the implementation of WTO regulation and the absence of Law regarding Industry and Trade. Using normative legal method, this research shows that countries which directly involved in free trade has the right to sell their products either goods or services to another country without having to be burdened by tax restrictions or customs duties and also without restricted by regulations. There should be an industrialized transformation immediately based on selective industrial policy. This thing needs to be done by merging the role of the Ministry of Industry and Ministry of Trade into one ministry, so there will be a strong industrial policy which can be a basic for policies in trade and investment too.

Keywords: globalization, industry, investment 


\section{A. Pendahuluan}

Pada abad ke-21 internasionalisasi dari kegiatan masyarakat dunia dalam hampir semua bidang akan semakin meningkat dan membawa kita pada perkembangan dalam gejala saling berkaitan di antara negara-negara di dunia. Perkembangan dalam teknologi dan pola kegiatan ekonomi membuat masyarakat di dunia semakin saling bersentuhan, saling membutuhkan, saling menentukan nasib satu sama lain, tetapi juga saling bersaing.

Hal ini terutama terlihat dalam kegiatan perdagangan dunia sebagai salah satu bidang utama dalam kegiatan eknomi masyarakat di dunia, baik dalam bidang perdagangan barang (trade in goods) maupun dalam bidang perdagangan jasa (trade in services). Karena dalam berinteraksi secara internasional satu lama lain dalam perdagangan dunia akan mengalami konflik dan perselisihan-perselisihan, maka negara-negara di dunia memerlukan suatu kesepakatan terhadap aturan main tertentu dalam suatu sistem perdagangan global.

Globalisasi yang terjadi saat ini di mana mengarah kepada suatu dunia seolah menjadi tidak terbatas (bordeless world) telah menempatkan semua penduduk dunia dalam suatu perkampungan global, dimana menurut Kinichi Ohmae dunia terintegrasi tanpa batas -batas fisik. Perkembangan dunia di era millenium III ditanda dengan semakin pesatnya loncatan kemajuan bidang ilmu pengetahuan dan teknologi (IPTEK). Perkembangan ini terasa semakin multi dimensi ketika dihadapkan pada tuntutan dan kebutuhan manusia yang beragam.
Kompleksitas ini semakin bertambah manakala dihubungkan dengan pola interaksi bisnis yang terjalin di masyarakat modern. Implikasi ini telah mengubah wajah perdagangan dan perekonomian dunia menjadi bentuk bisnis dalam perkampungan global (business in globall village). Kondisi ini dengan tepat digambarkan Daniel Davidson: "We are so economicially interdependent on one another that We so live in global village". ${ }^{1}$ Riuh rendah aktivitas tersebut pada akhirnya juga merambah bidang hukum yang notabene diharapkan senantiasa adaptif dan reaktif dalam merespon segala bentuk perubahan dan tantangan perkembangan zaman.

Globalisasi ekonomi berarti terintegrasinya ekonomi berbagai negara menjadi satu seolaholah tanpa dibatasi oleh kedaulatan negara. Salah satu ciri bisnis yang paling dominan pada globalisasi ekonomi adalah sifatnya bergerak cepat, baik dalam transaksi maupun pergerakan arus barang dan modal. Hal ini mempengaruhi pula terhadap berbagai peraturan di bidang bisnis yang dengan cepat pula mengalami perubahan.

Menurut William Irwin Thomson², bahwa, dengan dukungan teknologi dan informasi kecepatan perubahan tidak lagi menghitung abad, tahun, atau bulan, tetapi bisa terjadi setiap hari. Di berbagai pelosok, berlangsung transaksi bisnis tanpa mengenal penghentian, mulai dari penyiapan pertanahan Real Setate dan Industrial Estate seperti halnya investasi di bidang penanaman modal, pembentukan alat produksi, penyediaan bahan baku, perlengkapan dan perangkat kerja, pendistribusian produk 
dan transportasi darat, laut dan udara yang dibarengi dengan persetujuan asuransi, perdagangan, komunikasi, pembiayaaan dan sebagainya.

Dalam dekade terakhir ini atau sering juga disebut sebagai era globalisasi, batas nonfisik antarnegara semakin sulit untuk membedakannya dan bahkan cenderung batas (borderless state). Dampak yang sangat terasa dengan terjadinya globalisasi yakni arus informasi begitu cepat sampai ke masyarakat.

Globalisasi ekonomi yang ditandai dengan adanya keterbukaan perekonomian dialami hampir semua negara di dunia saat ini, telah membuat sistem perekonomian menjadi terbuka bebas. Kondisi tersebut telah diprediksi sebelumnya oleh Francis Fukuyama, dimana menurutnya prinsip-prinsip liberal dalam ekonomi telah menyebar dan berhasil memproduksi kesejahteraan material yang belum pernah dicapai sebelumnya.

Kalau perekonomian didasarkan pada mekanisme pasar, maka akan tercipta suatu keseimbangan (equilibrium). Dalam model pasar persaingan sempurna (perfect competition), pasar bersifat self regulating dan self correcting karena ada tangan tak terlihat (invisible hand) yang selalu dapat mengarahkan perekonomian pada keseimbangan pemanfaatan sumber daya penuh (full equilibrium) yang menguntungkan semua pihak dalam masyarakat. Salah satu asumsi penting dalam sistem ekonomi pasar bebas yang dikembangkan oleh Adam Smith lewat teori klasik laissez fairenya adalah bahwa setiap orang dibebaskan melakukan yang terbaik bagi dirinya masing-masing (individual freedom of action). Dalam sistem ini, keputusan tadi pada akhirnya akan menyumbang sebisa mungkin bagi terwujudnya suatu masyarakat yang lebih baik yang lebih adil, dan yang lebih makmur.

Ada 4 (empat) asumsi yang melandasi terciptanya suatu persaingan yang sempurna pada suatu pasar tertentu, yaitu: pelaku usaha tidak dapat menentukan secara sepihak harga atas produk dan jasa. Adapun yang menentukan harga adalah pasar berdasarkan equilibrium permintaan dan penawaran (supply and demand). Dengan demikian, pelaku usaha tidak bertindak sebagai price maker melainkan hanya sebagai price taker. Barang atau jasa yang dihasilkan oleh pelaku usaha adalah betulbetul sama (product homogeneity). Pelaku usaha memiliki kebebasan untuk masuk atau keluar dari pasar (perfect mobility of resources). Konsumen dan pelaku usaha memiliki informasi yang sempurna (perfect information) tentang berbagai hal, seperti: kesukaan (preferences), tingkat pendapatan (income levels), biaya (cost) serta teknologi yang digunakan untuk menghasilkan barang dan jasa.

Dari sudut pandang ekonomi, invisible hand adalah mekanisme alam yang memungkinkan kepentingan ekonomi seluruh masyarakat dapat dicapai dalam pasar bebas. Invisble hand adalah mekanisme tersembunyi yang akan mengubah kegiatan manusia untuk mengejar kepentingannya menjadi kegiatan yang membawa kesejahteraan seluruh masyarakat. Kesejahteraan masyarakat ini tercapai berkat penciptaan lapangan kerja, pertumbuhan ekonomi, peningkatan pendapatan nasional, perbaikan prasarana ekonomi, dan sebagainya. Yang semuanya merupakan konsekuensi logis dari kegiatan individual para pelaku ekonomi dalam mengejar kepentingannya.

Di era globalisasi ekonomi setiap negara menghadapi persaingan yang semakin ketat di 
dua medan perang, yakni perdagangan bebas serta foreign direct invesment/FDI (selanjutnya disebut investasi). Hal ini kemudian ditandai dengan diimplementasikannya perjanjian perdagangan bebas (Free Trade Agreement/FTA) dan perjanjian investasi (investment agreement) serta kemajuan teknologi informasi, yang menjadikan semakin terkikisnya hambatanhambatan perdagangan, lalu lintas keuangan internasional yang semakin bebas, dan keluar masuknya arus modal dan investasi di tiap-tiap negara. Dampak dari bergulirnya era globalisasi ini akan menimbulkan persaingan yang semakin ketat di antara negara-negara, sehingga hanya negara yang memiliki kemampuan bersaing saja yang akan mampu bertahan.

Implementasi dari globalisai ekonomi ditandai dengan terciptanya hubungan perdagangan secara internasional yang dilakukan secara bebas diantara individu-individu atau negara-negara. Pada dasarnya, esensi dari pelaksanaan perdagangan bebas tersebut mengacu pada 2 (dua) prinsip kebebasan, yaitu: pertama, adalah prinsip kebebasan berdagang (freedom of trade) di mana berdasarkan prinsip ini setiap negara atau individu memiliki kebebasan untuk berdagang dengan pihak manapun (negara maupun individu) di dunia ini. Kedua, adalah prinsip kebebasan untuk berkomunikasi (freedom of communication) di mana berdasarkan prinsip ini setiap negara memiliki kebebasan untuk memasuki wilayah dari negara lain untuk melakukan transaksitransaksi perdagangan secara internasional.

Demikian juga halnya arus transportasi dari satu negara ke negara lain dapat begitu cepat dan mudah diakses oleh masyarakat.
Hal ini semua tentu berkat dukungan teknologi yang terus digunakan dan dikembangkan oleh para ahlinya. Dengan semakin dekatnya batas antara satu negara dengan negara lain peluang untuk berinvestasi, terlebih lagi hampir semua negara dewasa ini sudah membuka diri bagi investor asing sangat terbuka luas. Oleh karena itu tidaklah berlebihan, jika pakar ekonomi Dorodjatun Kuntjoro-Jakti mengemukakan:

"Meningkatnya perekonomian di banyak negara ini, sebagai akibatnya adalah "interdepedensi" pada akhirnya menciptakan derajat keterbukaan ekonomi yang semakin tinggi di dunia, yang terlihat bukan hanya pada arus peningkatan barang tapi juga pada arus jasa serta arus uang dan modal. Pada gilirannya arus investasi di dunia semakin mengikuti perkembangan keterbukaan ini, sehingga dewasa ini peningkatan arus investasi itulah yang memacu arus perdagangan di dunia" ${ }^{3}$.

Untuk itu, cukup beralasan jika setiap negara saling bersaing untuk menarik calon investor khususnya investor asing (Foreign Direct Investment, FDI) untuk menanamkan modal di negaranya. Dalam suasana seperti ini peluang yang begitu terbuka di era globalisasi agaknya perlu disikapi secara positif.

Kehadiran investor asing dalam suatu negara yang berdaulat memang dapat menimbulkan berbagai pendapat dengan argumentasi masingmasing. Pendapat tersebut antara lain ada yang mengekemukakan, kehadiran investor asing dapat mengancam industri dalam negeri sendiri dan bahkan mungkin mengancam kedaulatan negara. Permasalahan semacam ini, bukannya tidak disadari oleh negara penerima modal (host country). Perhatikan misalnya apa yang dikemukakan oleh B. Napitupulu: 
“......kebijakan Pemerintah RI dalam menghadapi modal asing menunjukkan suatu keinginan untuk memberikan proporsi yang wajar sebagai potensi ekonomi negara-negara asing melalui sistem seleksi dan pengarahan yang adequate dengan kedaulatan tunggal yang dimiliki"4.

Pendapat senada diungkapkan oleh Rusdin:

"Salah satu kritik terhadap globalisasi adalah meningkatnya ketergantungan antara ekonomi global, kekuatan ekonomi yang menggantikan dominasi pemerintah dan memfokuskan kearah organisasi perdagangan bebas (WTO). Ketika dunia ini menjadi satu pasar berakibat pada semakin kuatnya interpedensi atau saling ketergantungan antara satu negara dengan negara lainnya yang sama-sama mempunyai kedaulatan nasional. Jadi yang sebenarnya terjadi bukanlah satu negara tergantung pada negara lainnya, melainkan suatu situasi dan kondisi di mana semuanya saling memerlukan untuk mempertahankan keseimbangan politis, ekonomis dan tentu pula dalam rangka pemenuhan kepentingan masingmasing negara"5.

Oleh karena itu, terbukanya hubungan antara satu negara dengan negara lainnya, terlebih lagi bagi negara-negara yang selama ini menutup diri dengan dunia luar, mulai membuka diri. Hal ini berarti peluang untuk berinvestasi cukup luas. Negara penerima modal pun menyadari bahwa implikasi yang akan muncul dengan kehadiran investor asing di negaranya suatu hal yang sulit untuk dihindari. Dalam hal inilah dibutuhkan leadership yang kuat dari penyelenggara negara, sebab negara membutuhkan modal dalam membangun berbagai sektor. Modal yang dimaksud di sini, tidak semata-mata berupa dana segar (fresh money), akan tetapi meliputi teknologi (technology), keterampilan (skill) serta sumber daya manusia (human resource). Hal ini dengan cermat dikemukakan oleh Usha Dar dan Pratap K Dar:

"Most developing countries today believe that it is not possible for them to achieve their development aspiration entirely on their own and therefore, need the cooperation of other relatively more developed countries. This cooperation may take the form direct investment or sharing of technical knowhow, skilled personal and management expertise"

Pendapat di atas menguatkan dalil, bahwa modal dibutuhkan untuk mengelola sumber daya alam (natural resource) dan potensi ekonomi (economic potential) yang berada di bawah otoritas negara. Adanya pengelolaan secara optimal terhadap sumber daya alam dan potensi ekonomi yang ada, diharapkan ada nilai tambah tidak saja bagi negara akan tetapi juga bagi masyarakat pada umumnya, khususnya pada masyarakat dimana potensi batubara tersebut berada. Adapun wujud pengelolaan sumber daya alam dan potensi ekonomi yang ada tersebut antara lain dapat dilakukan oleh investor baik lokal maupun asing. Untuk investor asing pada umumnya merupakan Perusahaan Multi Nasional, PMN (Multi National Corporation, MNC). Jenis perusahaan ini hampir dapat dipastikan telah mempunyai jaringan bisnis yang cukup kuat di berbagai negara. Sebagaimana yang diungkapkan oleh J. Panglaykim:

"Beberapa alasan terjadinya investasi langsung luar negeri yang dilakukan lewat

B. Napitupulu, Joint Ventures di Indonesia, (Jakarta: Erlangga, 1975), hlm. 30.

Rusdin, Bisnis Internasional dalam Pendekatan Praktik, Jilid 1, (Bandung: Alfabeta, 2002), hlm. 34.

6 Usha Dar dan Pratap K Dar. Investment Opportunities in ASEAN Countries. (New Delhi: Sterling Published Pvt, ltd, 1970), hlm. 1. 
MNC yakni: pertama, MNC memiliki keunggulan komparatif (comparative advantage) dan keunggulan khas yang dimiliki oleh suatu perusahaan (firm's specific advantage); kedua, keunggulan lokasi (location advantage); ketiga, internalisasi, termasuk pemilikan modal yang tidak terlihat dengan kasat mata (intangible assets) seperti keahlian di bidang pemasaran, manajemen dan teknologi. Selain keunggulan yang telah dikemukakan di atas, pada umumnya perusahaan yang berstatus MNC juga mempunyai: jaringan kantor cabang dan informasi di tingkat internasional; dukungan pemerintah; serta konglomerat yang terintergrasi secara vertikal dan horizontal dalam bisnis dan kelompok-kelompok industri. Berkat keunggulan inilah, pada umumnya MNC siap melakukan investasi langsung ke luar negeri" ${ }^{\prime \prime}$.

Berkaitan dengan kehadiran investor asing di suatu negara, menarik menyimak pendapat yang dikemukakan oleh Robert Gilpin dan Jean Milles Gilpin:

"Para penerima investasi langsung (Foreign Direct Investment, FDI) bersikap mendua menyangkut kegiatan MNC. Di satu sisi, mereka menyadari bahwa FDI membawa modal dan teknologi berharga ke dalam negara. Di sisi lain, mereka takut didominasi dan dieksploitasi perusahaan-perusahaan yang kuat ini"8.

Barangkali disinilah letak problematikanya, yaknidisatu sisi kehadiran FD/sangat dibutuhkan, terlebih lagi bagi negara-negara yang sedang berkembang. Di sisi lain, ada kekhawatiran berbagai pihak investor hanya berpikiran bisnis. Oleh karena itu tidaklah.berlebihan jika Bob Sugeng Hadiwinata mengemukakan:
"Ada sejumlah pakar ekonomi yang mengaitkan ekspansi PMN ke negara berkembang dengan dampak positif yang ditimbulkan oleh aktivitas PMN sehingga mendorong pemerintah negara berkembang untuk lebih membuka diri bagi investasi asing. Mereka pada umumnya bersepakat bahwa negara berkembang menginginkan investasi asing karena manfaat langsung yang dapat dirasakan dari kehadiran PMN. Selanjutnya dikemukakan: Dampak positif dari kehadiran PMN yakni pertama memberikan kontribusi pertumbuhan ekonomi suatu negara; kedua menciptakan lapangan kerja baru dan ketiga modal yang dibawa oleh PMN dapat memperbaiki neraca pembayaran negara berkembang?

Terlepas dari pendapat pro dan kontra terhadap kehadiran investasi asing, namun secara teoritis kiranya dapat dikemukakan, bahwa kehadiran investor asing di suatu negara mempunyai manfaat yang cukup luas (multiplier effect). Manfaat yang dimaksud yakni kehadiran investor asing dapat menyerap tenaga kerja di negara penerima modal; dapat menciptakan demand bagi produk dalam negeri sebagai bahan baku; menambah devisa apalagi investor asing yang berorientasi ekspor; dapat menambah penghasilan negara dari sektor pajak; adanya alih teknologi (transfer of technology) maupun alih pengetahuan (transfer ofknow how). Dilihat dari sudut pandang ini terlihat bahwa, kehadiran investor cukup berperan dalam pembangunan ekonomi suatu negara, khususnya pembangunan ekonomi di daerah di mana FDI menjalankan aktivitasnya. 
Arti pentingnya kehadiran investor asing dikemukakan oleh Gunarto Suhardi:

\begin{abstract}
"Investasi langsung lebih baik jika dibandingkan dengan investasi portofolio, karena investasi langsung lebih permanen. Selain itu investasi langsung juga memberikan kesempatan kerja bagipenduduk; mempunyai kekuatan penggandaan dalam ekonomi local; memberikan risidu baik berupa peralatan maupun alih teknologi; bila produksi diekspor memberikan jalan atau jalur pemasaran yang dapat dirunut oleh pengusaha lokal di samping seketika memberikan tambahan devisa dan pajak bagi Negara; lebih tahan terhadap fluktuasi bunga dan valuta asing; serta memberikan perlindungan politik dan keamanan wilayah karena bila investor berasal dari negara kuat niscaya bantuan keamanan juga akan diberikan"10.
\end{abstract}

Sekalipun kehadiran investor membawa manfaat bagi negara penerima modal, di sisi lain investor yang hendak menanamkan modalnya juga tidak lepas dari orientasi bisnis (business oriented), apakah modal yang diinvestasikan aman dan bisa menghasilkan keuntungan.

Dengan demikian menjadi sangat penting untuk dibahas bagaimana pelaksanaan pasar bebas Masyarakat Ekonomi ASEAN (MEA); serta bagaimana antisipasi pemerintah Indonesia dengan diberlakukan WTO serta Kehadiran Undang-undang Perindustrian dan Perdagangan?

\section{B. Metode Penelitian}

Penelitian ini merupakan suatu penelitian yuridis normatif. Sebagai suatu penelitian yuridis normatif, maka penelitian ini berbasis pada analisis terhadap norma hukum, baik hukum dalam arti law as it is written in the books and statutes (dalam literatur dan peraturanperundang-undangan). ${ }^{11}$ Titik berat analisis adalah norma hukum yang terdapat dalam literatur dan peraturan perundang-undangan.

\section{Tipe Penelitian}

Penelitian tentang " globalisasi, masyarakat ekonomi ASEAN, Indonesia dan investasi" merupakan penelitian hukum normatif. Penelitian hukum normatif yang difokuskan dalam penelitian ini, antara lain meliputi penelitian terhadap asas-asas hukum. ${ }^{12}$ Penelitian hukum normatif yang berupa penelitian mengenai asas-asas hukum, dilakukan terhadap kaedah-kaedah hukum yang merupakan patokan-patokan berperilaku atau bersikap tindak. Penelitian tersebut dapat dilakukan terutama terhadap bahan hukum primer dan sekunder, sepanjang bahanbahan tersebut mengandung kaedah-kaedah hukum, karena tidak setiap pasal dalam suatu perundang-undangan mengandung kaedah hukum, seperti: pasal-pasal yang hanya memuat batasan-batasan atau definisi-definisi dari suatu istilah sebagaimana lazimnya ditemukan pada bab mengenai ketentuan-ketentuan umum dan perundang-undangan tersebut.

\section{Metode Pendekatan}

Metode yang dipergunakan dalam penelitian ini adalah metode deskriptif analitis dengan pendekatan utamanya yuridis normatif. Deskriptif analitis berarti menggambarkan dan melukiskan sesuatu yang menjadi obyek

\footnotetext{
10. Gunarto Suhardi. Beberapa Elemen Penting dalam Hukum Perdagangan Internasional. (Yogyakarta: Universitas Atmajaya, 2004), hlm. 45.

11 Ronald Dworkin, Legal Research, (Daedalus: Spring,1973), hlm. 250.

12 Soerjono Soekanto, Penelitian Hukum Normatif, (Jakarta PT.Raja Grafindo Persada, 1985), hlm. 28.
} 
penelitian secara kritis melalui analisis yang bersifat kualitatif. Oleh karena yang ingin dikaji berada dalam ruang lingkup ilmu hukum, maka pendekatan normatif tersebut, meliputi: asasasas hukum, sinkronisasi peraturan perundangundangan, baik secara vertikal maupun horizontal, sistematika hukum, inventarisasi hukum positif, termasuk usaha penemuan hukum inconcreto. ${ }^{13}$

Di dalam suatu penelitian yuridis normatif, maka penggunaan pendekatan perundangundangan (statute approach) adalah suatu hal yang pasti. Dikatakan pasti, karena secara logika hukum, penelitian hukum normatif didasarkan pada penelitian yang dilakukan terhadap bahan hukum yang ada. Meskipun misalnya penelitian dilakukan karena melihat adanya kekosongan hukum, namun kekosongan hukum tersebut dapat diketahui, karena sudah adanya normanorma hukum yang mensyaratkan pengaturan lebih lanjut dalam hukum positif. ${ }^{14}$

\section{Pembahasan}

\section{Pasar Bebas Masyarakat Ekonomi ASEAN (MEA)}

Bagi Indonesia, globalisasi tidak dapat dihindari, untuk mengatasi hal tersebut maka yang harus diperhatikan adalah kebijakan ke depan untuk menghadapi globalisasi tersebut sehingga kita tidak hanya sekedar menjadi pelengkap di rumah sendiri.

Demikian halnya dengan adanya kesepakatan perdagangan di negara-negara ASEAN yang akan diterapkan pada tahun 2015, sebagaimana dalam pertemuan tingkat tinggi Kerja Sama Ekonomi Asia Pasifik 2013 di Bali. Kesepakatan dalam forum 21 pemimpin ekonomi ini semakin mengukuhkan kerja sama ekonomi berbasis neoliberal. Setelah perdagangan dan investasi, kini bertambah lagi liberalisasi sektor jasa.

Liberalisasi menjadi keniscayaan ketika suatu negara terikat perjanjian perdagangan bebas (FTA). Indonesia termasuk di dalam perjanjian kerja sama ASEAN FTA (AFTA), kerja sama AFTAJepang, AFTA Indiea, AFTA China, AFTA Korea, dan AFTA Australia-Selandia Baru.

Indonesia tidak sendiri dalam mengintegrasikan perekonomiannya pada pasar dunia. Dalam lingkup anggota APEC, penurunan tajam rata-rata bea masuk barang impor juga dialami China, Peru, Filipina, Thailand, dan Vietnam.

Namun, liberalisasi yang berjalan sejauh ini lebih banyak menempatkan Indonesia sebagai pasar ketimbang sebaliknya. Liberalisasi tidak diikuti peningkatan kemampuan produksi pangan, energi, dan industri manufaktur dalam negeri menyebabkan banjir barang impor. Kebijakan impor yang mulanya bersifat 
sesekali ketika dibutuhkan berubah menjadi impor struktural karena ketergantungan yang tinggi. Perlindungan terhadap produsen lokal terabaikan. Tahun depan, persoalan pangan tetap akan diselesaikan secara instan, melalui impor.

Liberalisasi tidak selamanya berdampak negatif. Hanya saja, Indonesia belum bisa mengambil manfaat sebesar-besarnya. Liberalisasi keuangan dinilai punya dampak positif terhadap pertumbuhan ekonomi internal negara berkembang secara bertahap dan dalam kondisi fundamental baik. Namun perlu kehatihatian terhadap dana panas (hot money) yang gampang ditarik investor asing.

Pemerintah harus mampu memanfaatkan liberalisasi untuk kemajuan lebih baik dengan meningkatkan daya saing produsen domestik. Diperlukan kebijakan yang melindungi masyarakat kelas bawah dan meningkatkan kapasitas pelaku ekonomi skala kecil.

Keberanian pemerintah melakukan transformasi dan dukungan kelembagaan untuk memperbaiki infrastruktur, industri, dan pertanian merupakan keharusan. Jika tidak, liberalisasi tidak akan memberi manfaat bagi Indonesia.

Tahun 2015 akan menjadi tahun penentuan bagi perekonomian Indonesia, terutama dengan mulai berlaku efektifnya Masyarakat Ekonomi Asia: Indonesia akan menjadi pemenang, atau sebaliknya pecundang di kawasan.

Salah satu yang paling ekstensif, ambisius, dan di depan mata adalah Masyarakat Ekonomi ASEAN, yang salah satu pilarnya adalah pembentukan pasar tunggal ASEAN pada 2015 atau dua tahun dari sekarang. Di ASEAN sendiri kesepakatan perdagangan bebas bilateral (BTA) ditempuh karena kemajuan AFTA dianggap terlalu lamban. Masyarakat Ekonomi Asia (MEA) yang akan menjadikan ASAN pasar tunggal dan basis produksi kompetitif di kawasan, juga bentuk dari respons ASEAN terhadap bangkitnya ekonomi China dan India.

Sebagai pasar tunggal, semua hambatan perdagangan, baik tarif maupun tarif, akan dihapuskan. Antisipasi terutama harus kita lakukan terkait liberalisasi sektor jasa sebagai sektor sensitif. Lima sektor jasa yang disepakati diliberalisasi adalah jasa kesehatan, pariwisata, e-commerce, transportasi udara, dan logistik. Kelimanya pada 2015 akan bebas diperdagangkan lintas negara. Perdagangan jasa mengatur liberalisasi tenaga kerja profesional dan buruh manufaktur. Untuk profesional ada lima kategori yang disepakati mulai beroperasi bebas 2015, yaitu perawat, dokter, dokter gigi, akuntan, dan insinyur. Tenaga profesional dan buruh yang melintas batas negara ini harus memenuhi standar yang sudah ditetapkan di ASEAN.

Bentuk lahirnya ASEAN Charter yang ditandatangani oleh 10 negara ASEAN pada 20 November 2007, yang dapat menjadi landasan hukum bagi kerja sama ASEAN. Salah satu tujuan lahirnya ASEAN Charter adalah:

"committed to intensfiying community building through enhanced regional cooperation and integration, in particular by establishing an ASEAN community comprising The ASEAN Security Community, The ASEAN Economic Community, and The ASEAN Sociocultural Community".

Khusus tujuan ASEAN - Charter dalam aspek sosial-ekonomi, antara lain menyangkut poinpoin nomor 5, 6, 9, 10 dan 11 sebagai berikut:

To create a single market and production base which is stable, prospereous, highly competitive and economically integrated with effective facilitation for trade and investment in which there is free flow of goods, services and investment; facilitated movement of business persons, professionals, talents and 
labor; and free flow of capital (poin 5); To aleviate proverty and narrow the development gap within ASEAN through mutual assistance and cooperation (poin 6); To promote sustainable development so as to ensure the protection of the region's environment, the sustainability of its natural resources, the preservation of its cultural heritage and the high quality of life of its peoples (poin 9); To develop human resources through closer cooperation in education and longlife learning, and in science and technology, for enpowerment of the peoples of ASEAN and for the strengthening of the ASEAN Community (poin 10); To enhance the wellbeing and livelihood of the peoples ASEAN by providing them with equitable access to opportunity for human development, social welfare and justice (poin 11).

Jika melihat ke-5 (lima) point yang terdapat dalam deklarasi ASEAN menyangkut sosialekonomi dari ASEAN Charter tersebut, menyangkut tujuan komunitas ekonomi ASEAN, yaitu: pembentukan pasar tunggal, pemberantasan kemiskinan, proteksi lingkungan, pengembangan SDM dan Iptek untuk pemberdayaan rakyat, dan jaminan akses bagi rakyat menggapai pembangunan manusia, kesejahteraan dan keadilan sosial.

Seperti juga dalam menerjemahkan Pancasila dan UUD NRI 1945, khususnya untuk menyangkut tujuan sosial-ekonomi, akan membutuhkan penjabaran dalam peraturan perundang-undangan, paradigma/platform, kebijakan dan dan strategi yang tepat untuk mencapai tujuan nasional, yakni: melindungi segenap bangsa Indonesia dan seluruh tumpah darah, memajukan kesejahteraan umum, mencerdaskan kehidupan bangsa, dan ikut melaksanakan ketertiban dunia (Pembukaan
UUD NRI 1945). Maka dari itu, dalam mencapai tujuan ASEAN Charter pun akan tergantung paradigma/platform, kebijakan dan strategi operasional yang tepat untuk mencapai tujuan kolektif kesepuluh negara ASEAN.

Dengan demikian, kiranya solusi ekonomi kerakyatan berbasiskan UUD 45 dapat menjadi pioner untuk mengisi paradigma, kebijakan dan strategi yang tepat dalam mencapai tujuan sosial-ekonomi ASEAN yang intinya baik dalam bidang kesejahteraan, keamanan maupun perdamaian, di masing-masing negara ASEAN, regional ASEAN secara kolektif serta dunia pada umumnya.

ASEAN Investment Area mempunyai tiga komponen, yaitu fasilitasi investasi, promosi investasi, serta liberalisasi investasi. Kegiatan yang sedang berjalan di bidang fasilitasi investasi dan promosi investasi harus didukung dengan kuat melalui pembentukan "ASEAN Regional Unit" sebagai suatu lembaga baru. Lembaga ini bisa dimulai dengan menjadikannya bagian dari ASEAN Secretariat. ${ }^{15}$

Melihat perkembangan global maupun di wilayah ASEAN, komponen liberalisasi investasi tidak lagi memberikan perlakuan preferensial bagi investor ASEAN. Dalam banyak hal tidaklah tepat bagi negara-negara ASEAN bahwa dalam rangka liberalisasi rejim investasi mereka negara-negara ASEAN harus mendapat preferensi terlebih dahulu sebelum preferensi yang sama diberikan kepada investor-investor non-ASEAN. ${ }^{16}$

Sebagaimana dikatakan selain pasar tunggal ASEAN yang berlaku tahun 2015, sebelumnya telah ada 19 (sembilan belas) kesepakatan sejak 
tahun 2011 mengenai perdagangan bebas (FTA) dimana 7 (tujuh) diantaranya telah berjalan, 1 (satu) belum mulai berlaku, 3 (tiga) masih dalam status negosiasi, 2 (dua) dalam status negosiasi, tetapi kerangka kesepakatannya sudah ditanda tangani, serta 6 (enam) masih berstatus usulan.

Dari 7 (tujuh) yang telah berjalan hanya satu yang FTA bilateral, yakni kesepakatan kemitraan ekonomi (EPA) Indonesia-Jepang, sedangkan 6 (enam) sisanya FTA yang ditandatangani Indonesia sebagai bagian dari ASEAN, termasuk AFTA. ${ }^{17}$

Untuk membuat ASEAN menjadi landasan produksi tunggal yang kompetitif sangatlah penting untuk menarik FDI yang berkualitas paling baik dalam kuantitas yang sebesar mungkin terlepas dari country of origin. Harus kita ingat bahwa arus masuk investasi langsung tidak digerakkan oleh negara-negara anggota ASEAN, melainkan oleh perusahaan-perusahaan multinasional Amerika Serikat, Uni Eropa dan Jepang.

Masuknya perusahaan multinasional ASEropa dan Jepang harus dapat dipahami oleh ASEAN bahwa kesepakatan yang telah dibuat harus dapat diimplementasikan, tidak seperti halnya yang terjadi di Indoensia, begitu investor mulai melakukan aktivitasnya selalu terhambat dengan kepentingan daerah tertentu, hal ini bertentangan dengan kesepakatan dalam WTO maupun ASEAN saat ini.

Di dalam rangka ini ASEAN memang harus membuat dua keputusan penting, pertama, Melangkah lebih jauh dari rekomendasi HLTF yang tercantum di dalam Bali Concord /I dan membuka semua sektor manufaktur bagi investasi asing. Hal ini tentu berarti bahwa tidak perlu lagi ada temporary exclusion list (TEL) dan sensitive list dalam sektor manufaktur, dengan menggunakan ASEAN-X formula. Kedua, ASEAN harus membuka diri bagi semua investor, jadi tidak lagi ada perbedaan antara invetasi dari ASEAN dan non-ASEAN.

Apabila melihat kesepakatan dalam Bali Concord II khususnya dalam hal penerbangan maka yang terjadi adalah pihak Indonesia mengalami kerugian dengan pembagian wilayah penerbangan khususnya perjanjian dengan pihak Malaysia. ${ }^{18}$

Untuk membangun suatu landasan produksi tunggal, ASEAN harus mendorong pembentukan jejaring produksi regional di Asia Tenggara. Kecenderungan global dalam manufaktur menunjukkan suatu pergeseran ke adopsi teknik-teknik produksi yang fleksibel dan pembangunan jejaring produksi yang terintegrasi. Kompetisi yang keras berarti bahwa tidaklah lagi cost effective apabila seluruh rangkaian manufaktur dilakukan di dalam satu perusahaan (in-house) atau di dalam satu negara. Untuk mempersingkat rangkaian dan waktu produksi dan pengantaran ke pasar yang cepat, perusahaan-perusahaan multinasional mengintegrasikan kegiatan manufaktur mereka di berbagai lokasi dan memperkenalkan teknik manajemen Just-In-Time dan seringkali melalui subkontrak internasional. Kecenderungan produksi global ini berarti bahwa tidak hanya mencari pasar yang lebih besar, melainkan juga tempat-tempat di mana mereka dapat membangun jejaring produksi yang efisien.

17 Sri Hartati, Perdagangan Internasional Indonesia dan Globalisasi, dalam Tinjauan Kompas, Menatap Indonesia 2014, Tantangan, Prospek Politik dan Ekonomi Indonesia, (Jakarta: Kompas, 2014), hlm. 67-68.

18 Rusli, M, Opensky Bali Concord II ASEAN, (Padang: (tanpa penerbit), 2012), hlm. 120. 
Strategi perusahaan multinasional yang kini muncul menunjukkan bahwa mereka sudah rencanakan untuk memanfaatkan wilayah Asia Tenggara sebagai landasan produksi untuk dapat memperbesar volume penjualan mereka di pasar ASEAN dengan sekaligus mengembangkan sarana perolehan komponen di wilayah ASEAN, peningkatan spesialisasi produk untuk mencapai economies of scale, dan pementingan keuntungan atas dasar operasi di wilayah ASEAN.

HLTF on ASEAN Economic Integration juga menyarankan pembentukan jejaring ASEAN Free Trade Zones, sehingga perusahaanperusahaan dapat menstrukturkan proses manufaktur mereka melintasi berbagai negara ASEAN "to take advantage of their cooperative strengths" dan di dalam proses itu meningkatkan perdagangan dan investasi intra-ASEAN. Kemudian, ASEAN harus pula "undertake more effective joint ASEAN facilitation and promotion measures and develop new sources of inward FDI", seperti dari China, India dan Republik Korea, untuk melengkapi FDI dari AS, UE dan Jepang.

Arus bebas barang manufaktur sangat penting untuk mempromosikan ASEAN sebagai landasan produksi tunggal. ASEAN sudah melaksanakan liberalisasi perdagangan melalui AFTA. Dalam rangka penurunan tarif suatu kemajuan yang besar sudah dicapai dengan AFTA. Arus bebas tidak hanya berarti penghapusan tarif, melainkan harus sekaligus pula berarti penghapusan rintangan non-tarif.

ASEAN harus mengusahakan penghapusan rintangan tarif dalam perdagangan intraASEAN, khususnya barang-barang manufaktur. Bagi beberapa negara, termasuk negara-negara CMLV, hal ini merupakan suatu tantangan karena tarif atas perdagangan internasional merupakan bagian yang besar bagi pemasukan negara. Hal ini memang harus dihadapi dan mekanisme harus dicari untuk mengatasinya.

Suatu analisa dari perdagangan infra-ASEAN memperlihatkan adanya landasan produksi regional di ASEAN. Suatu penurunan dalam saham produk yang berlandaskan sumber daya alam (resource-based products) dalam perdagangan intra-ASEAN selama 20 tahun disertai dengan peningkatan ekspor produk listrik dan elektronik, yang kini hampir mencapai separoh dari arus dagang ASEAN, sebagian besar daripadanya suku cadang dan komponen. Kecenderungan ini menunjukkan suatu potensi yang jelas bagi production sharing sebagai bagian dari jejaring produksi regional.

Akses yang meningkat sebagai akibat dari penurunan rintangan tarif dan non-tarif tidaklah cukup untuk menjamin arus barang yang bebas di ASEAN. Biaya transaksi yang tinggi bagi perdagangan internasional yang disertai antara lain bea-cukai yang tidak efisien dan standar yang tidak jelas dapat menurunkan nilai perdagangan secara signifikan.

ASEAN perlu segera mengupayakan penurunan biaya transaksi ini dengan cepat dan drastis. Upaya untuk menurunkan biaya transaksi ini memerlukan suatu komitmen yang jauh lebih besar daripada upaya yang diperlukan untuk menyelesaikan masalah akses pasar.

Inisiatif fasilitasi ini sering memerlukan pembentukan badan-badan baru atau perombakan total lembaga-lembaga yang sudah ada. Lagi pula, usaha ini hams dilakukan semua negara ASEAN secara bersama-sama, semua negara anggota harus mengimplementasikan paling sedikit suatu rangkaian minimal dari inisiatif-inisiatif utama, khususnya yang berkaitan dengan upaya untuk 
mengharmonisasikan prosedur perbatasan dan standarisasi.

Pemerintah-pemerintah ASEAN harus memusatkan sumber dayanya, baik ekonomi, maupun politik, untuk menjamin bahwa fasilitasi ini tidak hanya akan mengurangi biaya transaksi, melainkan pada akhirnya juga mendukung perwujudan Masyarakat Ekonomi ASEAN.

HLTF merekomendasikan integrasi jalur cepat dari 4 sektor jasa yang diprioritaskan, yaitu e-ASEAN, jasa kesehatan, perjalanan udara dan pariwisata. HLTF juga merekomendasikan bahwa integrasi sektor jasa diimplementasikan melalui liberalisasi yang dipercepat sektorsektor prioritas ini, pengembangan MRA yang dipercepat, dan pendorong joint ventures dan kerjasama, termasuk pasar negara ketiga.

Integrasi sektor jasa harus memfasilitasi proses pembangunan landasan produksi tunggal ASEAN. Inisiatifinisiatif regional harus pula ditujukan untuk mempromosikan low cost high quality service industries yang memungkinkan ASEAN mengembangkan diri sebagai suatu outsourcing hubungan global.

Di samping keempat sektor prioritas di atas, ASEAN harus pula mempertimbangkan untuk mempercepat sektor-sektor jasa: Jasa keuangan (seperti banking and capital markets); telekomunikasi; jasa bisnis profesional (seperti akuntansi dan hukum); logistik dan transportasi; pendidikan; serta energi.

Integrasi sektor jasa dapat pula dipercepat dengan memasukkan industri jasa ke dalam liberalisasi investasi di bawah ASEAN Investment Area (AIA), yang dipertimbangkan ASEAN. Liberalisasi sektor jasa ini harus pula dilakukan ke luar ASEAN. Hal ini berarti bahwa ASEAN Framework Agreement on Services (AFAS) harus ditinggalkan untuk suatu jalur alternatif yang lebih cepat. Salah satu jalur di sini ialah mengadopsi suatu kebijakan ASEAN bagi pembukaan sektor-sektor jasa prioritas secara global. Kebijakan ini dengan sendirinya berarti pula kebijakan imigrasiyang terbuka bagi tenaga kerja profesional dan trampil.

\section{Antisipasi Pemerintah Indonesia Dengan Diberlakukan WTO Serta Kehadiran Undang-Undang Perindus- trian Dan Perdagangan}

Memperhatikan ketentuan pada saat Ministreal Meeting to the APEC Summit 2004 bahwa tanpa melihat sistem ekonomi yang bagaimanapun yang diterapkan oleh suatu negara maka setiap negara bergerak ke arah yang sama yaitu persaingan global dan perdagangan bebas. ${ }^{19}$ Perdagangan bebas merupakan media yang efektif dan damai dalam peningkatan kekayaan masing-masing negara. Karena negara-negara diuntungkan dengan kerjasama perdagangan yang akan meningkatkan kesejahteraan masyarakatnya. ${ }^{20}$ Lebih dari itu, agar terciptanya a peaceful global order, sistem dunia harus diarahkan menuju sebuah pasar global, di mana barang dan jasa dapat bergerak bebas melintasi batasan-batasan negara. ${ }^{21}$

19 Harian Kompas, "ASEAN Berencana Menjadi "Pasar Tunggal”. 7 Oktober 2003, Rizal Malaranggeng, Mendobrak Sentralisme Ekonomi, Indonesia 1986-1992, (Kepustakaan Popular Gramedia bekerja sama dengan Freedom Institute, 2004), hlm. 19-33.

20 Scott Burchill \& Andrew Linklater, Theories of International Relation, (The United States of America: St. Martin's Press. Inch., 1996), hlm. 32.

21 Handy Hady, Ekonomi Internasional, Teori dan Kebijakan Perdagangan Internasional, Indonesia: Ghalia, 2001), hlm. 65. 
Josep E. Stiglitz menjelaskan capaiancapaian positif dari perdagangan bebas sebagai akibat dari proses globalisasi ekonomi yang melanda dunia, yaitu:

Opening up to international trade has helped many countries grow far more quickly than they would otherwise have done. International trade helps economic development when a country's exports drive its economic growth. Export led growth was the centerpiece of industrial policy that enriched much of Asia and left millions of people in the world now live longer than before and their standard of living is far better off. Because of globalization many people in the world now live longer than before and their standard of living is far better...Globalization has reduced the sense of isolation felt in much of the developing world and has given many people in the developing countries acces to knowledge well beyond the reach of even the wealthiest in any country a century a go. ${ }^{22}$

Beberapa kalangan berpendapat bahwa globalisasi ekonomi merupakan kekuatan positif bagi pembangunan Negara-negara sedang berkembang yang telah lebih dulu membuka diri terhadap perdagangan bebas (free trade) dan penanaman modal asing (foreign investment) seperti China, India, Malaysia, Thailand, Vietnam dan Indonesia untuk negara-negara di kawasan Asia, Argentina dan Mexico untuk negara di Amerika Latin, Hunggaria dan Polandia di Eropa Timur, serta Ghana dan Uganda di Afrika, ternyata telah mencapai pertumbuhan ekonomi yang lebih tinggi dibandingkan denga periode sebelumnya. ${ }^{23}$

Untuk dapat mengatasi ini maka ke depannya Pemerintah Indonesia telah membuat MP3EI, Integrasi ke dalam rezim rantai industri dan perdagangan global. Mengangkat Indonesia menjadi negara maju dan merupakan kekuatan 10 besar dunia di tahun 2030 dan 6 besar dunia pada tahun 2050 melalui pertumbuhan ekonomi tinggi yang inklusif dan berkelanjutan adalah rencana ambisius yang hendak dikejar Indonesia dengan meluncurkan sebuah program baru bernama Masterplan Percepatan dan Perluasan Pembangunan Ekonomi Indonesia (MP3EI). Sebagaimana namanya, maka MP3EI merupakan strategi pembangunan Indonesia yang baru, yang diadakan karena berubahnya lingkungan geoekonomi global, khususnya dinamika yang terjadi di Asia Timur yang sekarang menjadi center of economic gravity. MP3Ei disebut sebagai upaya "transformasi ekonomi" oleh negara yang bersifat "not business as usual", dan merupakan sebuah terobosan yang bersifat percepatan dan perluasan. $M$ enurut pemerintah, IMF telah memproyeksikan bahwa Indonesia ada di antara 18 ekonomi terbesar dunia pada tahun 2009-2015 yang akan menjadi ekonomi dengan pertumbuhan tercepat yaitu $12,8 \%$. Ini lebih tinggi dari Rusia yang $12,5 \%$, Tiongkok yang $12,3 \%$ serta India yang $11,8 \%$. Visi 2025 dari MP3EI adalah sebagai berikut:

a. Pada tahun 2014, PDB Indonesia akan menjadi US\$ 1,2 triliun, dengan pendapatan perkapita US\$ 4.800, dan menjadi kekuatan ekonomi dunia ranking ke-14 terbesar;

b. Pada tahun 2025, PDB Indonesia akan menjadi US\$ 3,8-4,5 triliun, dengan pendapatan per-kapita US\$ 13.000-16.100, dan menjadi kekuatan ekonomi dunia ranking ke-12 terbesar; dan

22 Josepf E. Stiglitz, Globalization and Its Dsicontent, (Australia: Penguin Books, 2002), hlm. 4.

23 Nicholas Stern, "Globalization and Property", makalah dalam seminar LPEM Fakultas Ekonomi Universitas Indonesia, (2000). 
c. Pada tahun 2045, PDB Indonesia akan menjadi US\$16,6 triliun, dengan pendapatan perkapita US\$ 46.900, dan menjadi kekuatan ekonomi dunia ranking ke-7/8 terbesar dunia. $^{24}$

Visi 2025 diwujudkan melalui 3 misi yang menjadi fokus utama, yaitu:

a. Peningkatan nilai tambah dan perluasan rantai nilai proses produksi serta distribusi dari pengelolaan aset dan akses (potensi) DSA, geografis wilayah, dan SDM, mealui penciptaan kegiatan ekonomi yang terintegrasi dan sinergis di dalam maupun antar-kawasan pusat-pusat pertumbuhan ekonomi;

b. Mendorong terwujudnya peningkatan efisiensi produksi dan pemasaran serta integrasi pasar domestik dalam rangka penguatan daya saing dan daya tahan perekonomian nasional;

c. Mendorong penguatan sistem inovasi nasional di sisi produksi, proses, maupun pemasaran untuk penguatan daya saing global yang berkelanjutan menuju innovation-driven economy. ${ }^{25}$

Fokus dari pengembangan MP3EI ini diletakkan pada 8 program utama, yaitu pertanian, pertambangan, energi, industri, kelautan, pariwisata, dan telematika, serta pengembangan kawasan strategis. Kedelapan program utama tersebut terdiri dari 22 kegiatan ekonomi utama. Inisiatif strategis MP3EI adalah dengan: (1) mendorong realisasi investasi skala besar di 22 kegiatan ekonomi utama tersebut; (2) Sinkronisasi rencana aksi nasional untuk merevitalisasi kinerja sektor riil; dan (3) Pengembangan center of excellence di setiap koridor ekonomi. Sementara strategi utama MP3El adalah: (1) Pengembangan potensi ekonomi melalui Koridor Ekonomi; (2) Penguatan konektivitas; dan (3) Penguatan kemampuan SDM dan Iptek nasional. ${ }^{26}$ Dalam hal koridor ekonomi ini, maka dinyatakan bahwa:

Percepatan dan Perluasan Pembangunan Ekonomi Indonesia diselenggarakan berdasarkan pendekatan pengembangan pusat-pusat pertumbuhan ekonomi, baik yang telah ada maupun yang baru. Pendekatan ini pada intinya merupakan integrasi dari pendekatan sektoral dan regional. Setiap wilayah mengembangkan produk yang menjadi keunggulannya.

Pengembangan pusat-pusat pertumbuhan ekonomi dilakukan dengan mengembangkan klaster industri dan Kawasan Ekonomi Khusus (KEK). Pengembangan pusat-pusat pertumbuhan tersebut disertai dengan penguatan konektivitas antar-pusat-pusat pertumbuhan ekonomi dan antara pusat pertumbuhan ekonomi dengan lokasi kegiatan ekonomi serta infrastruktur pendukungnya. Secara keseluruhan, pusat-pusat pertumbuhan ekonomi dan konektivitas tersebut menciptakan Koridor Ekonomi Indonesia (KEI). ${ }^{27}$

UU Perindustrian No. 3 Tahun 2014 ini dengan mudah bisa dilihat merupakan alat neoliberal untuk menghapus substansi pasal 33 UUD

24 Lihat Kementerian Koordinator Bidang Perekonomian, Masterplan Percepatan dan Perluasan Pembangunan Ekonomi Indonesia 2011-2025, Istana Bogor, 11 Februari 2011. Juga lihat “Pengembangan Koridor Ekonomi Indonesia: Kick-off Meeting Penyusunan MP3EI, Hotel Borobudur, Jakarta, 7 Februari 2011.

25 Kementerian Koordinator Bidang Perekonomian, Masterplan Percepatan dan Perluasan Pembangunan Ekonomi Indonesia 2011-2025, (MP3EI), Jakarta, cetakan I, Mei 2011 (versi final).

26 Ibid, MP3EI Mei 2011, hlm. 24.

27 Ibid, MP3EI Mei 2011, hlm. 31. 
45 yang masih dianut dalam UU no. 5/1984. Tidak ada lagi ketentuan atau kalimat mengenai cabang-cabang industri yang penting dan strategis bagi negara dan menguasai hajat hidup orang banyak dikuasai oleh Negara. Kalimatkalimat tersebut sudah dihapus di dalam UU baru ini. Sebaliknya UU Perindustrian yang baru adalah untuk "menciptakan iklim usaha yang menunjang terbentuknya peningkatan daya saing sektor industri. Oleh karena itu pengaturan yang kurang menunjang upaya pembentukan daya-saing perlu dihilangkan, dengan mengganti pengaturan yang mendorong kemudahan dalam usaha." Kalimat dalam penjelasan UU baru ini jelas menunjuk pada ideologi persaingan (pasar bebas) yang berkehendak menghapus aturan-aturan yang membatasi persaingan dan kebebasan berusaha, khususnya oleh pihak swasta maupun swasta asing.

UUbaruinijugamengarah padapenyambutan atas dinamika globalisasi ekonomi, yaitu sebagai bagian dari rezim rantai nilai/pasokan global yang sekarang sedang berkembang luas di dunia. Ini Nampak dari definisi industri itu sendiri yang bunyinya "Industri adalah kegiatan ekonomi yang mengolah bahan baku dan/atau memanfaatkan sumber daya industri sehingga menghasilkan barang yang mempunyai nilai tambah atau manfaat lebih tinggi, termasuk jasa industri.

Pada tanggal 13 Februari 2014 DPR juga telah menyetujui UU Perdagangan yang baru, setelah cukup lama dibahas di DPR. RUU Perdagangan ini punya semangat yang sama dengan UU Perindustrian baru tersebut, yaitu semangat liberalisme perdagangan ala WTO. Terkesan bahwa, UU Perdagangan ini disiapkan untuk menyambut rezim perdagangan bebas yang semakin marak dewasa ini, lewat paket Bali WTO dan berbagai kesepakatan bilateral
FTA. Bahkan sebenarnya alotnya penyelesaian RUU Perdagangan sebenarnya juga hendak menyambut rezim pasar bebas yang lebih baru lagi, yang dikenal sebagai rezim rantai pasokan. Karena itu tidak heran bahwa isi-isi yang terkandung di dalam UU Perdagangan pada akhirnya memuat semua pengaturan kearah tersebut. Hal ini bisa dilihat dalam penerapan asas equal-treatment (kesamaan perlakuan) antara pemain asing dengan pemain nasional, yang sudah ditetapkan juga di dalam UU Penanaman Modal No. 25 Tahun 2007. Sebenarnya baik UU Perindustrian dan UU Perdagangan ini mengacu kepada UU Nomor 25 Tahun 2007. Induk dan benteng dari aturan liberalisme yang paling kuat adalah di UU tersebut. Keduanya mengacu penuh kepada UU Nomor 25 Tahun 2007.

UU Perdagangan juga secara jelas hanya merujuk pada ayat 4 pasal 33 UUD 45, dan bukan pada ayat 1-3 pasal 33 UUD 45 (lihat bagian Penjelasan UMUM). Ini adalah penjelasan eksplisit yang menyatakan bahwa sebenarnya UU Perdagangan ini memilih pada versi liberal dari pasal 33 UUD 45, yang memang menjadi jalan bagi liberalisasi atas berbagai sektor ekonomi sebagaimana yang dikehendaki ayat 5 pasal 33 UUD 45 (amandemen). Karenanya jelas harus diadakan revisi atas UU Perdagangan yang baru ini.

\section{Penutup}

Dengan adanya perdagangan bebas, tidak ada lagi hambatan yang dibuat oleh suatu negara dalam melakukan suatu transaksi perdagangan dengan negara lainnya. Negara-negara di dunia atau yang terlibat langsung dalam perdagangan bebas mempunyai hak untuk menjual produk baik barang ataupun jasa terhadap negara lain tanpaharus dibebanioleh batasan-batasan pajak 
atau bea masuk. Dengan adanya perdagangan bebas, diharapkan interaksi antarnegara dalam perdagangan menjadi lebih intensif tanpa harus dibatasi oleh peraturan yang membelenggu di dalam negeri negara tujuan. Dengan demikian kalangan industri dapat mengimpor barang yang dibutuhkan untuk memacu kegiatan produksi dan mengekspor produk jadi ke pasar regional demi memperbaiki volume perdagangan dalam negeri.

Kehadiran hambatan perdagangan internasional berupa faktor budaya, sosial dan hukum terus menyajikan tantangan bagi para pelaku usaha yang memutuskan untuk bergerak melalui forum organisasi internasional seperti World Trade Organization (WTO) dan Masyarakat Ekonomi Asean demi menggulirkan inisiatif liberalisasi perdagangan kepada pemerintah baik di tingkat regional maupun multilateral. Globalisasi dan pasar bebas diharapkan dapat membawa kesejahteraan dan pertumbuhan, namun hanya bagi segelintir orang karena sebagian besar dunia ini tetap menderita. Ketika budaya lokal makin hilang akibat gaya hidup global, tiga perempat penghuni bumi ini harus hidup dengan kurang dari dua dolar sehari. Satu miliar orang harus tidur dengan kelaparan setiap malam. Satu setengah miliar penduduk bola dunia ini tidak bisa mendapatkan segelas air bersih setiap hari. Satu ibu mati saat melahirkan setiap menit.

Untuk itu harus segera dijalankan sebuah transformasi industrialisasi berdasarkan sebuah kebijakan industrial (industrial policy) yang selektif, sehingga dengan potensi dan kekayaan sumber daya alamnya tidak lama lagi akan menjadi Negara industri maju. Hal ini perlu dilakukan dengan cara penguatan peran Kementerian Perindustrian dan Perdagangan menjadi satu kementerian, sebagaimana yang dilakukan Negara-negara maju lainnya, agar ada satu kebijakan industri yang kuat dan bahwa kebijakan perdagangan dan investasi harus menginduk kepada kebijakan industri.

\section{DAFTAR PUSTAKA}

\section{Buku}

Abdurrachman, A, Ensiklopedia Ekonomi Keuangan Perdagangan, (Jakarta: Pradnya Paramita, Cet. ke 6, 1991).

Adelman, Irma and Cynthia Taft Maorris, Comparative Patterns Of Economis Development, 1850-1914 (Baltimore, MD: Johns Hopkins University Press. 1988).

Budiman, Arief, Teori Negara, Negara, Kekuasaan, dan Ideologi, (Jakarta: Gramedia, 2002)

Dar, Usha dan Pratap K Dar. Investment Opportunities in ASEAN Countries. (New Delhi: Sterling Published Pvt, Itd, 1970).

Departemen Kehakiman RI, Badan Pembinaan Hukum Nasional, Laporan Akhir: Penelitian Tentang Aspek Hukum Perdagangan Dikaitkan dengan Penanaman Modal Asing. (Jakarta, 1996).

Departemen Pendidikan dan Kebudayaan RI. Kamus Besar Bahasa Indonesia (KBBI). (Jakarta: Balai Pustaka, Edisi keempat, 1995).

Elliot Goodman, Jordan dan John Downes, Kamus Istilah Keuangan \& Investasi. Alih bahasa oleh Soesanto Budhidarmo (Jakarta : Elex Media Komputendo, 1994).

Erawaty, A.F Elly dan J.S.Badudu. Kamus Hukum Ekonomi Indonesia Inggris. (Jakarta: ELIPS, edisi pendahuluan, 1996).

Gilpin, Robert dan Jean Mules Gilpin, The Challenge of Global Capitalism (Tantangan Kapitalisme Global) Penerjemah: Haris Munadar, Dudy Priatna. (Jakarta: Raja Grafindo Persada, Ed. 1, Cet 1, 2002).

Hartati, Sri, Perdagangan Internasional Indonesia dan Globalisasi, dalam Tinjauan Kompas, Menatap Indonesia 2014, Tantangan, Prospek Politik dan Ekonomi Indonesia, (Jakarta: Kompas, 2014).

Hartono, CFG Sunaryati, Globalisasidan Perdagangan Bebas, (Jakarta: BPHN Departemen Kehakiman, 1998). 
J.Theberge, Leonard, "Law and Economic Development,"Journal of International Law and Policy, Vol. 9, (1980).

Luhulima, C.P.F., Dinamika Asia Tenggara Menuju 2015, (Jakarta: Pustaka Pelajar \& LIPI, 2011).

M. Friedman, Lawrence, American Law, (New York: W.W. Norton and Company, 1984).

Napitupulu, B, Joint Ventures di Indonesia. (Jakarta: Erlangga, 1975).

Rusdin, Bisnis Internasional dalam Pendekatan Praktik. Jilid 1. (Bandung: Alfabeta, 2002).

Rusli, M, Opensky Bali Concord II ASEAN, (Padang: (tanpa penerbit), 2012).

Sugeng Hadiwinata, Bob, Politik Bisnis Internasional (Yogyakarta: Kanisius, Cet. 1, 2002).

Suhardi, Gunarto, Beberapa Elemen Penting dalam Hukum Perdagangan Internasional. (Yogyakarta: Universitas Atmajaya, 2004).

Sumantoro, Bunga Rampai Permasalahan Penanaman Modal/ Problems of Investment in Equities and in Securities. (Bandung: Binacipta, 1990).
Suparno, Penegakan Hukum Penanaman Modal di Indonesia, (Bandung: Citra Aditya Bakti, 2010).

Winardi, Kamus Ekonomi (Inggris-Indonesia) (Bandung: Alumni, Cet. 8, 1982).

Yanto Bashri (ed), Mau Ke Mana Pembangunan Ekonomi Indonesia. Prisma Pemikiran Prof. Dr. Dorodjatun Kuntjoro-Jakti. (Jakarta: Predna Media, 2003).

\section{Makalah/ Artikel/ Prosiding/ Hasil Penelitian}

A Coss, Ronald, The Rule of Law In America, 1-22 (2001), dalam Rohit Sachdev, "Comparing The Legal Fondations of Foreign Direct Investment in India and China: Law and Rule Of Law In The Indian Foreign Direct Investment Context" Columbia Journal of Law \& the Arts, Vol.25 (2001).

M. Friedman, Lawrence, "On Legal Development," Rutgers Law Review, (Vol.23, 1969).

Panglaykim, J. "Era Pasca Minyak Identik dengan Strategi Eskpor Nasional." Dalam Analisa, Tahun XIV, No.1, (Januari, 1985). 